This report was prepared as an account of work sponsored by an agency of the United States Government. Neither the United States Government nor any agency thereof, nor any of their employees, makes any warranty, express or implied, or assumes any legal liability or responsibility for the accuracy, completeness, or usefulness of any information, apparatus, product, or process disclosed, or represents that its use would not infringe privately owned rights. Reference herein to any specific commercial product, process, or service by trade name, trademark. manufacturer, or otherwise does not necessarily constitute or imply its endorsement, recommendation, or favoring by the United States Government or any agency thereof. The views and opinions of authors expressed herein do not necessarily state or reflect those of the United States Government or any agency thereof.

\title{
Lymphocytes from Wasted Mice Express Enhanced Spontaneous and $\gamma$-ray-induced Apoptosis ${ }^{1}$
}

Gayle E. Woloschak, ${ }^{*+1}$ Chin-Mei Chang-Liu, Jen Chung, and Claudia R. Libertin ${ }^{\ddagger .8}$

Running Title: $\quad$ Apoptosis in Wasted Mice

Key Words:

apoptosis; $\gamma$ rays; ionizing radiation; programmed cell death; wasted mice

${ }^{1}$ This work supported by the U.S. Department of Energy, Office of Health and Environmental Research, under Contract No. W-31-109-ENG-38. 


\section{FOOTNOTES}

'To whom correspordence should be addressed at current address

${ }^{\dagger}$ Biological and Medical Research Division, Argonne National Laboratory, 9700 South Cass Avenue, Argonne, Ilinois 60439-4833

${ }^{\ddagger}$ Department of Pathology, and ${ }^{8}$ Department of Medicine, Loyola University Medical Center, 2160 South First Avenue, Maywood, Mlinois 60153

Abbreviations Used: $w s t$, wasted allele; wst/., unaffected littermates of $w s t / w s t$ mice (should be $67 \%$ wst $/+, 33 \%+/+$ ) 
ABSTRACT

Mice bearing the autosomal recessive mutation wasted ( $w s t / w s t)$ display a disease pattern including faulty repair of DNA damage in lymphocytes after radiation exposure, neurologic abnormalities, and immurodeficiency. Many of the features of this mouse model have suggested a premature or increased spontaneous frequency of apoptosis in thymocytes; past work has shown an inability to establish cultured $\mathrm{T}$ cell lines, an abnormally high death rate of stimulated $\mathrm{T}$ cells in culture, and an increased sensitivity of $\mathrm{T}$ cells to the killing effects of ionizing radiations in $w s t / w s t$ mice relative to controls. The experiments reported here were designed to examine splenic and thymic lymphocytes from wasted and control mice for signs of early apoptosis. Our results revealed enhanced expression of Rp-8 mRNA (which has been associated with apoptosis) in thymic lymphocytes and reduced (undetected) expression in splenic lymphocytes of wst / wst mice relative to controls; expression of Rp-2 and Tcl-30 mRNA ( $a_{i}$ io reported to be induced during apoptosis) were not detectable in spleen or thymus. Expression of Rp-2, Rp-8, and Tcl-30 mRNA in other affected tissues of wasted mice (brain, spinal cord, liver) were similar in wasted mice and controls. Higher spontaneous DNA fragmentation was observed in wasted mice than in controls; however, $\gamma$-ray-induced DNA fragmentation peaked at a lower dose and occurred to a greater extent in wasted mice relative to controls. These results provide evidence for high spontaneous and $\gamma$-ray-induced apoptosis in $\mathrm{T}$ cells of wasted mice as a mechanism underlying the observed lymphocyte and DNA repair abnormalities. 


\section{INTRODUC'TION}

Mice bearing the autosomal recessive mutation wasted ( $w s t / w s t$ ) are known to express a variety of abnormalities including faulty repair of DNA damage in lymphocytes after exposure to ionizing radiations, immunodeficiency, and neurologic abnormalities (1-5). While some B cell abnormalities have been observed $(2,6)$, the primary lymphocytic defect is thought to reside in the T cell population $(7,8)$. Premature involution of the thymus, increased thymic retrovirus expression, and abnormal responsiveness to $\mathrm{T}$ cell mitogens have all been identified in wasted mice compared with littermate controls and compared with control strains (1,7-9). The inability to cultured $\mathrm{T}$ cell clones from wasted mice and their lack of viability after mitogenic stimulation in culture (10) has suggested a possible defect in the regulation of thymic/T-lymphocyte apoptosis. Experiments were designed to examine measures of apoptosis in wasted mice compared with those in control littermates ( $w s t / \cdot)$ and parental controls $\left(\mathrm{BCF}_{1}\right)$.

Recent works have identified several means of quantifying apoptosis in mice including DNA fragmentation assays, which determine the breakage pattern of DNA after induction of the apoptotic response in cells $(11,12)$; in addition, several groups have identified genes induced during programmed cell death, such as $\mathrm{Rp}-2$ and $\mathrm{Rp}-8$ genes reported by Owens et al. (13) and the Tcl-30 gene reported by Baughman et al. (14). We report the results of our experiments that were designed to examine expression of genes associated with apoptosis and to measure DNA fragmentation in lymphocytes from wasted and control mice before and after $\gamma$-ray exposure. Our results are consistent with those from models of premature thymocyte apoptosis and increased sensitivity of lymphocytes to 
$\gamma$-ray-induced apoptosis in wasted mice as a feature underlying many of the observed immunologic abnormalities in this animal model. 


\section{MATERIALS AND METHODS}

Mice. Breeding pairs of mice bearing the wasted mutation $(w s t /+)$ were obtained from The Jackson Laboratory, Bar Harbor, ME. Our mice were bred in the animal facility of the Biological and Medical Research Division at Argonne National Laboratory under sterile conditions. Because it is possible that $w s t /+$ heterozygotes may express immunologic abnormalities when compared with wild type $(+/+), \mathrm{BCF}_{1}$ mice were also used as a control strain. For all experiments, affected mice 23--28 days of age were used, and unaffected littermates and age-matched $\mathrm{BCF}_{1}$ mice served as controls. In all experiments, we have observed no differences in apuptotic responses between 23- and 28day-old mice.

Irradiations and Cycloheximide Treatments. Splenic and thymic lymphocytes were purified by centrifugation through Ficoll gradi ats. Cells were exposed to the indicated doses (50-600 çyy) of ${ }^{60} \mathrm{Co} \gamma$ rays at a dose rate of $14 \mathrm{cGy} / \mathrm{min}$. We selected radiation dose and dose-rate based on previously shown sensitivities of lymphocytes of wasted mice to $\gamma$ rays $(10,15)$. Cells were incubated for one or three $h$ (as indicated throughout) after exposure and then harvested. Cycloheximide $(0-50 \mu \mathrm{g} / \mathrm{mL})$ was added to cultures in a volume of $1-10 \mu \mathrm{L}, 10$ min before irradiations. These concentrations were shown to have no effect on cell viability at $3 \mathrm{~h}$ after treatment.

Northern Blots. The RNA was prepared by extraction with phenol and precipitation from $3 \mathrm{M}$ sodium acetate, $\mathrm{pH} 6.0$ (16-17). Pcly(A)+ RNA was isolated by oligodeoxythymidylate cellulose chromatography until no unbound material absorbing at $254 \mathrm{~nm}$ was detected. RNA was stored as an ethanol precipitate at $-20^{\circ} \mathrm{C}$. Routinely, we found that poly(A)+ RNA represented $5-10 \%$ of the total RNA fraction. 
The RNA was separated by using formaldehyde-agarose gel electrophoresis as described previously (16). Samples of poly(A)+ RNA (amounts in micrograms, as indicated in figure legends) were denatured in $50 \%$ formamide, $1.9 \mathrm{M}$ formaldehyde, $0.2 \mathrm{M} 3-[\mathrm{N}$ morpholino]propanesulfonic acid, $50 \mathrm{mM}$ sodium acetate, and $1 \mathrm{mM} \mathrm{Na} \mathrm{EDTA}_{2} \mathrm{pH} 7.5$, for $15 \mathrm{~min}$ at $55^{\circ} \mathrm{C}$ and then separated on $1.2 \%$ agarose gels in $0.2 \mathrm{M} 3-[\mathrm{N}$ morpholinolpropanesulfonic acid, $50 \mathrm{mM}$ sodium acetate, $1 \mathrm{mM} \mathrm{Na}{ }_{2}$ EDTA, and $2.2 \mathrm{M}$ formaldehyde. The rRNA (Escherichia coli and mouse) and RNA ladder (BRL Laboratory, Bethesda, MD) markers were stained with ethidium bromide and photographed under UV light for use in sizing.

Northern transfers were performed as described previously (16). Blots were hybridized to ${ }^{32} \mathrm{P}$-nick-translated or oligo-labeled cDNA probes. Hybridization conditions were $50 \%$ deionized formamide, $0.75 \mathrm{M}$ sodium chloride, $75 \mathrm{mM}$ sodium citrate, $25-50 \mathrm{mM}$ sodium phosphate ( $\mathrm{pH} 6.5$ ), $0.2 \%$ SDS, $0.2 \% \mathrm{BSA}, 0.2 \%$ ficoll, $0.2 \%$ polyvinylpyrrolidone, and sonicated denatured herring sperm DNA $(50 \mu \mathrm{g} / \mathrm{mL})$ at $43^{\circ} \mathrm{C}$. Prior to hybridization, all labeled probes were heat-denatured at $90{ }^{\circ} \mathrm{C}$ for $5 \mathrm{~min}$. After hybridization, nonspecific binding was reduced by washing the hybridized blots three times for $1 \mathrm{~h}$ each at $43{ }^{\circ} \mathrm{C}$ in $45 \mathrm{mM}$ sodium citrate ( $\mathrm{pH} 7.4$ ), $0.45 \mathrm{M}$ sodium chloride, $0.2 \%$ ficoll, $0.2 \%$ polyvinylpyrrolidone, $0.2 \% \mathrm{BSA}$, herring sperm DNA (50 $\mathrm{gg} / \mathrm{mL}$ sonicated and denatured), $0.1 \% \mathrm{SDS}$ and then three times for $1 \mathrm{~h}$ each in $1.5 \mathrm{mM}$ sodium citrate $(\mathrm{pH} 7.4), 15 \mathrm{mM}$ sodium chloride, herring sperm DNA (50 $\mu \mathrm{g} / \mathrm{mL}$ sonicated and denatured), and 0.1\% SDS. The blots were then dried and exposed $九$ x-ray film at $-20^{\circ} \mathrm{C}$.

In some experiments, the same blot was washed and hybridized successively to several different probes. Each probe was eluted by washing for $24 \mathrm{~h}$ in distilled, deionized water at $43^{\circ} \mathrm{C}$, and blots were checked (for total removal of the labeled probes) by $24-\mathrm{h}$ 
exposure to $\mathrm{x}$-ray film. Blots were washed three times in hybridization buffer before rehybridization to a different probe. All blots are representative of results from three independent experiments.

A.though equal amounts (based on weight) of RNA were loaded into each well of a given gel, as determined by spectrophotomet $t_{2}$, we found sufficient variation from one preparation to another to make poly $(A)+$ analysis essential. Systems for mRNA analysis measuring the molar concentration of RNA with 3'poly(A) tails (Molecular Genetics Resources, Tampa, FL) were used for all poly(A)+ RNA preparations, and only RNA samples showing equimolar concentrations of poly(A)+ RNA were loaded onto the same gel.

DNA Fragmentation Assay. Splenic or thymic lymphocytes from two to four mice were harvested by collecting cells that remain at the interface following ficoll gradients sedimeritation. The cells were washed three times in PBS prior to lysis in $10 \mathrm{mM}$ Tris (pH 7.5), 1 mM EDTA, and $0.2 \%$ Triton. The DNA was separated by centrifugation $(13,000 \times \mathrm{g}$ for $20 \mathrm{~min})$ into fragmented DNA (supernatant) and intact DNA (pellet). Both fractions were digested with RNase $\mathrm{A}\left(50 \mu \mathrm{g} / \mathrm{mL}, 1 \mathrm{~h}\right.$ at $\left.37^{\circ} \mathrm{C}\right)$, and proteinase $\mathrm{K}(50$ $\mu \mathrm{g} / \mathrm{mL}, 1 \mathrm{~h}$ at $37^{\circ} \mathrm{C}$ ), extracted with phenol-chloroform, and precipitated from alcohol. DNA was quantitated by diamino-benzoicacid-spectrofluorimetry as described for submicrogram amounts of DNA (17). Percentage of fragmented DNA was calculated as the fraction of DNA in the supernatant divided by the total DNA (in supernatant and in pellet). DNA was separated by electrophoresis in $2 \%$ agarose - E Buffer gels (40 mM Tris, pH 7.7, $40 \mathrm{mM}$ sodium acetate, $\left.2 \mathrm{mM} \mathrm{Na} \mathrm{ED}^{\prime} \mathrm{TA}\right)$.

cDNA clones. The authors wish to thank G. P. Owens (University of Colorado, Denver) for providing Rp-8 and Rp-2 cDNA clones, S. Bourgeois (Salk Institute, La Jolla, CA) for 
providing the Tcl-30 clone, L. Kedes (Stanford University, Palo Alto, CA) for providing isotype-specific actin clones, and D. McKean (Mayo Clinic, Rochester, MN) for providing IL2 cDNA clone, for this work.

\section{RESULTS}

Gene Expression Studies. In initial experiments, we wished to determine whether genes associated with cellular apoptosis were expressed abnormally in immunodeficient $w s t / u s t$ mice relative to controls. Figure 1 presents the results of several Northern blots examining accumulation of Rp-8 mRNA in spleen, thymus, liver, brain, and spinal cord of wst/wst mice, wst/. littermates, and age-matched $\mathrm{BCF}_{1}$ controls. From these results, it is apparent that thymic and lymphocytes express enhanced levels of Rp-8-specific mRNA in wst/wst mice, moderately high levels in wst/. mice, and low levels in $\mathrm{BCF}_{1}$ mice. Splenic lymphocytes from $w s t / w s t$ mice expressed low (undetectable) levels of Rp-8 mRNA compared to $w s t / \cdot$ and $\mathrm{BCF}_{1}$ cells (Fig. $1 \mathrm{~B}$ ). Other transcripts (IL2 or $\gamma$ - $/ \beta$-actin) are detectable and equally expressed in all RNA preparations (not shown). In nonlymphoid tissues, levels of Rp-8 mRNA in wst/wst mice were no different from those in controls Figs. (1C-E).

Two other cDNA clones associated with apoptosis, Rp-2 and Tcl-30, were analyzed in experiments similar to those described above for Rp-8. In all experiments, under ou: conditions, both Rp-2 and Tcl-30 transcripts were detected only in brain-derived preparations, and differences between wasted mice and controls were not evident (data not shown).

DNA Fragmentation Studies. Apoptosis can be measured by DNA fragmentation as described by numerous investigators $(11,12)$. Figures 2 and 3 present results of agarose gels separating DNA fragments (supernatants) and intact DNA (pellets) from lymphocyte 
preparations isolated from spleen and thymus of $\mathrm{BCF}_{1}, w s t / w s t$, or $w s t /$ mice; cells were either untreated ( $0 \mathrm{cGy}$ ) or exposed to $50-600 \mathrm{cGy}{ }^{60} \mathrm{Co} \gamma$ rays. In both thymus (Fig. 2) and spleen (Fig. 3), the majority of fragmented DNA is found in the supernatant fraction and that this fragmentation is of the ladder-type, character stic of the apoptotic response $(11,12)$. There is less fragmented DNA in untreated cells than in the irradiated cells. All experiments depicted in Figures 2 and 3 are from cells harvested $3 \mathrm{~h}$ after completion of the radiation exposure. In initial experiments in which cells were harvested $1 \mathrm{~h}$ after completion of the exposure, DNA fragmentation was only rarely detected.

We then designed experiments to measure the percentage of fragmented DNA relative to the total after exposure to varying doses (0--600 cGy) of $\gamma$ rays. DNA content in pellets and supernatants was quantitated using spectrofluorimetry. Table I documents the results of experiments performed by using thymic lymphocytes, and Table II shows results of experiments with splenic lymphocytes. These data demonstrate a marked increased spontaneous apoptosis in thymocytes of wst/wst mice and increased sensitivity of $w s t / w s t$ mice and $w s t /$. littermates to $\gamma$-ray-induced fragmentation relative to controls. The absence of DNA fragmentation at higher doses denotes cell killing as a direct result of the radiation rather than through apoptosis.

The results of previous work by several groups (18-20) have shown the need for protein synthesis in the induction of DNA fragmentation of lymphocytes and other cell types after exposure to $\gamma$ rays. On the basis of the findings of Sellins and Cohen (18) in lymphocytes, we designed experiments to determine whether the lymphocytes from $w s t / w s t$ mice were able to induce DNA fragmentation in the presence of the protein synthesis inhibitor cycloheximide. Table III presents the results of experiments documenting reduced $\gamma$-ray-induced DNA fragmentation in thymocytes of control mice 
after cycloheximide treatment, as had been shown previously by Sellins and Cohen (18). We noted that the same effect also occurred by $u$ ing thymocytes from $w s t /$ and $w s t / w s t$ mice. Similar results were obtained by using splenocytes (datà not shown), demonstrating that while there is an increased sensitivity to $\gamma$-ray-induced apoptosis in wasted mice, the mechanism of anoptosis requires protein synthesis in lymphocytes derived from wasted and control mice.

It should be noted that all data presented for percentage of fragmented DNA are from one experiment but are representative of results from three independent experiments. We have noted a variation in the actual percentage of DNA in the supernatant but not in the trend of the change. The absolute levels of fragmented DNA in the untreated sample varied from 0-20\% depending on the cell viability and quality of the DNA preparation. However, the pattern from one dose to another was similar in all experiments.

\section{DISCUSSION}

The results reported in this manuscript describe abnormalities in apoptosis in thymic lymphocytes from wasted mice and their littermates relative to parental controls. This mouse mod' 1 has been considered a model for the human disease ataxia telangiectasia $(1,2)$, and many reports document the $\mathrm{T}$ cell nature of the primary defect (1,7-9). We examined two measures of apoptosis-expression of apoptosis - induced genes (Rp-8, Rp-2, Tcl-30) and DNA fragmentation. These experiments revealed (a) high expression of Rp-8 mRNA, (b) increased spontaneous apoptosis, and (c) increased sensitivity to $\gamma$-ray-induced DNA fragmentation in thymocytes from wasted mice relative to their unaffected littermates; and wst/. littermates were similarly more sensitive than 
$\mathrm{BCF}_{1}$ controls. We believe the premature apoptosis is related to early thymic involution and increased radiation sensitivity of wasted mice relative to controls $(1,10,16,17)$.

Splenic lymphocytes expressed a pattern opposite from that found in thymic lymphocytes. Rp-8 mRNA was not detected in spleen cells from $w s t / w s t$ mice but was evident in splenic lymphocyte preparations from $\mathrm{BCF}_{1}$ and $w s t /$. control mice. Expression in splenocytes from normal mice has been documented previously by Owens et al. (13). The failure of splenocytes from wst/wst mice to express this transcript is not surprising in light of past work from our group demonstrating a "reversal" in gene and protein expression in $w s t / w s t$ thymocytes and $w s t / w s t$ spleen cells relative to what one finds in control mice $(2,10)$. It is also interesting that, while apoptosis correlated with high accumulation of Rp-8 mRNA in thymocytes, such a relationship was not evident in spleen cell populations. These results suggest that high expression of $\mathrm{Rp}-8 \mathrm{mRNA}$ may be necessary but not sufficient for induction of apoptosis (as measured by DNA fragmentation) in lymphocytes.

Previous work has documented the high sensitivity of $\mathrm{T}$ cells from wasted mice to the killing effects of $\gamma$ rays (10). This is likely to occur as a result of the induction of apoptosis at radiation doses not usually harmful to lymphocytes. The mechanism(s) responsible for this high spontaneous apoptosis and increased $\gamma$-ray-induced apoptosis in wasted mice is unknown. This could be a primary defect in wasted mice or the result of some other abnormality in the strain. The results of work by Sellins and Cohen (18) and other groups $(19,20)$ have shown the requirement for protein synthesis in the induction apoptosis in thymocyte populations. Our results confirmed their findings in control mice and also demonstrated that this inductive pathway is intact in wasted mice since DNA fragmentation in both strains was inhibited by cycloheximide treatment. 
The fact that the abnormality in $\gamma$-ray-induced apoptosis is detected in both wasted mice and in unaffected littermates is not surprising in light of previous work by our group $(2,9)$ and by others $(4,7)$, documenting partial or overcompensational abnormalities in unaffected $w s t /$ littermates relative to normal mouse controls. This is remarkably similar to the pattern observed in lymphocytes from patients with ataxia telangiectasia in which heterzygotes express a partial defect in radiation sensitivity/DNA repair compared with controls $(20,21)$.

Results from our group have shown that the wasted mice demonstrate multiple cytokine abnornialities relative to controls (22). In particular, work from our group has shown decreased levels of IL5 mRNA in thymus from wasted mice compared with controls (20), while work by Stern et al. (23) has since shown that IL5 prevents apoptotic responses in eosinophils. The fact that other cytokines have also been implicated in apoptosis (24-27) and that we have identified several cytokine abnormalities in wasted mice suggests that a primary cytokine defect may underlie the abnormal apoptotic response in these animals. Interestingly, a report by Lin et al. (28) has demonstrated that depletion of thymic CD4+CD8+cells is correlated with apoptosis and DivA fragmentation. Previous work from our group (29) has documented low CD4+CD8+cells in thymus from wst / wst mice relative to $\mathrm{BCF}_{1}$ controls. Further experiments will be needed to identify the precise mechanism. The results of recent work by several groups $(30,31)$ have demonstrated accelerated programmed cell death in T-lymphocytes from MRL $l p r / l p r$ mice that express a systemic lupus erythematosus-like autoimmune disorder. How this model relates to the wasted-mouse model in the apoptotic response is unknown, but we believe the wasted mice may be useful in future studies as another model for abnormal apoptosis. 


\section{ACKNOWLEDGMENTS}

The authors wish to thank Gordon Holmblad for his assistance in irradiations, Kay Bexson for excellent secretarial assistance, and Drs. Carol Giometti, Frank Collart, Cheryl Denault, and Lydia Ling-Indeck for review of this manuscript. 


\section{REFERENCES}

1. Schultz, L. D., H. O. Sweet, M. J. Davisson, and D. R. Conan. 1982. "Wasted," a new mutant of the mouse with abnormalities characteristic of ataxia telangiectasia. Nature 297:402-404.

2. Woloschak, G. E., M. Rodriguez, and C. J. Krco. 1987. Characterization of immunologic and neuropathologic abnormalities in "wasted" mice. J. Immunol. 138:2493-2499.

3. Tezuka, H., T. Inoue, T. Noguti, T. Kada, and L. D. Shultz. 1986. Evaluation of the mouse mutant "wasted" as an animal model for ataxia telangiectasia. I. Agedependent and tissue-specific effects. Mutat. Res. 161:83-90.

4. Goldowity, D., P. M. Shipman, J. F. Porter, and R. R. Schmidt. 1985. Longitudinal assessment of immunologic abnormalities of mice with the autosomal recessive mutation, "wasted". J. Immunol. 135:1806-1812.

5. Woloschak, G. E., C. J. Krco, and M. Rodriguez. 1988. Influences of the microenvironment on B-cell responses of wasted mice: Comparison of Peyer's patches and mesenteric lymph nodes. Regional Immunol. 1:163-171.

6. Kaiserlian, D., D. Delacroix, and J. F. Fach. 1985. The wasted mutant mouse. I. An Animal model of secretory IgA deficiency with normal serum IgA. J. Immunol. 135:1126-1131.

7. Kaiserlian, D., W. Savino, J. Uriel, J. Hassid, M. Dardenne, and J. F. Bach. 1986. Immunological abnormalities in a mouse described as a model of ataxiatelangiectasia. Clin. Exp. Immunol. 63:562-569. 
8. Kaiserlian, D., M. D. Howell, and M. F. Kagnoff. 1987. Production of murine leukemia virus in the immunodeficient wasted mutant mouse is associated with wst allele. Immunol. Lett. 15:277-283.

9. Gavinski, S., and G. E. Woloschak. 1989. Expression of viral and virus-like elements in DNA repair-deficient/immunodeficient wasted mice. J. Immunol. 142:1861-1866.

10. Padilla, M., C. R. Libertin, C. Krco, and G. E. Woloschak, 1990. Radiation sensitivity of T-lymphocytes from immunodeficient "wasted" mice. Cell. Immunol. 130:186-194.

11. Mangan, D. F., and S. M. Wahl. 1991. Differential regulation of human monocyte programmed cell death (ajoptosis) by chemotactic factors and pro-inflammatory cytokines. J. Immunol. 147:3408-3412.

12. Ramakrishnan, N., and G. N. Catravas. 1992.(N-2-Mercaptoethyl)-1,3propanediamine (WR-1065) protects thymocytes from programmed cell death. $J$. Immunol. 148:1817-1821.

13. Owens, G. P., W. E. Hahn, and J. J. Cohen. 1991. Identification of mRNAs associated with programmed cell death in immature thymocytes. Molec. Cell. Biol. 8:4177-4188.

14. Baughman, G., J. Lesley, J. Trotter, R. Hyman, and S. Bourgeois. 1992. Tcl-30, a new $\mathrm{T}$ cell-specific gene expressed in immature glucocorticoid-sensitive thymocytes.J. Immunol. 149:1488-1496.

15. Inoue, T., ix. Aikawa, H. Tezuke, T. Kada, and L. Shultz. 1986. Effect of DNA damaging agents on isolated spleen cells from the mouse mutant "wasted," a putative animal model for ataxia telangiectasia. Can. Res. 46:3979-3982. 
16. Woloschak, G. E., C. J. K^o, and M. Rodriguez. 1989. Anti- $\mu$ treatment suppresses immunoglobulin light-chain gene expression and Peyer's patch development. Molec. Immunol. 26:351-358.

17. Woloschak, G. E., and C. J. Krco. 1987. Regulation of $k / \lambda$ immunoglobulin light chain expression in normal murine lymphocytes. Molec. Immunol. 24:751-757.

18. Sellins, K. S., and J. J. Cohen. 1987. Gene induction by $\gamma$-irradiation leads to DNA fragmentation in lymphocyłes. J. Immunol. 139:3199-3206.

19. Story, M. D., L. C. Stephens, S. P. Tomasovic, and R. E. Meyn. 1992. A role for calcium in regulating apoptosis in rat thymocytes irradiated in vitro. Int. J. Radiat. Biol. 61:243-253.

20. Inouye, M., M. Tamaru, and Y. Kameyama. 1992. Effects of cycloheximide and actinomycin $\mathrm{D}$ on radiation-induced apoptotic cell death in the developing mouse cerebellum. Int. J. Radiat. Biol. 61:669-674.

21. Nordeen, S. K., V. G. Schaefer, M. H. Edgell, C. A. Hutchinson III, L. D. Schultz, and M. Swift. 1984. Evaluations of wasted mouse fibroblasts and SV-40 transformed human fibroblasts as models of ataxia telangiectasia in vitro. Mutat. Res. 140:219-222.

22. Woloschak, G. E., M. E. Churchill, and C. R. Libertin. 1991. Immunological disorders characterizing the "wasted" mouse: a review. Immunol. (Life Sci. Adv.) 10:95-104.

23. Stern, M., L. Meagher, J. Savill, and C. Haslett. 1992. Apoptosis in human eosinophils. Programmed cell death in the eosinophil leads to phagocytosis by macrophages and is modulated by IL-5. J. Immunol. 148:3543-3549. 
24. Mangan, D. F., B. Robertson, and S. M. Wahl. 1992. IL-4 enhances programmed cell death (apoptosis) in stimulated human monocytes. J. Immunol. 148:1812-1816.

25. Zubiaga, A. M., E. Mũnoz, and B. Huber. 1992. IL-4 and IL-2 selectively rescue Th cell subsets from glucocorticoid-induced apoptosis. J. Immunol. 146:3857-3863.

26. Uehara, T., T. Miyawaki, K. Ohta, Y. Tamaru, T. Yokoi, S. Nakamura, and N. Taniguchi. 1992. Apoptic cell death of primed CD45RO+T lymphocytes in Epstein-Barr virus induced infectious mononucleosis. Blood 80:452-458.

27. Migliorati, G., C. Pagliacci, R. Moraca, F. Crocicchio, I. Nicoletti, and C. Riccardi. 1992. Interleukins modulate glucocorticoid-induced thymocyte apoptosis. Int. J. Clin. Lab. Res. 21:300-303.

28. Lin, Y. S., H. Y. Lei, T.-L. Low, C. L. Shen, L. J. Chou, and M. S. Jan. 1992. In vivo induction of apoptosis in immature thymocytes by staphylococcal enterotoxin B. J.Immunol. 149:1156-1163.

29. Woloschak, G. E., and C. R. Libertin. 1990. T-cell subset distributions in spleen, thymus and MLN from wasted mice (Short report). In Advances in Mucosal Immunology. MacDonald, Challacombe, Bland, Stokes, Heatley, and Mowat, eds. Kluwer Academic Publishers, London, pp. 180-181.

30. Van Houten, N., and R. C. Budd. 1992. Accelerated programmed cell death of MRLrlpr/lpr T lymphocytes. J. Immunol. 149:2513-2517.

31. Peitsch, M., T. Hesterkamp, B. Polzar, H. G. Mannherz, and J. Tschopp. 1992. Functional characterisation of serum DNase I in MRL-lpr/pr mice. Biochem. Biophys. Res. Commun. 186:739-745. 


\section{FIGURE LEGENDS}

Figure 1. Northern blots of (A) thymus-, (B) spleen-, (C) spinal cord-, (D) brain-, and

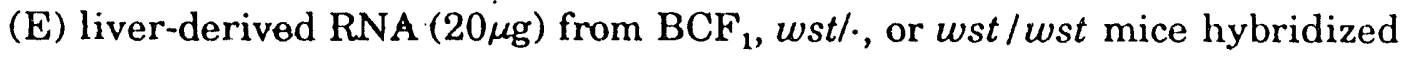
to labeled Rp-8 cDNA. RNA preparations were pooled from 5 to 10 mice. (It should be noted that exposure times are different for each photograph to allow for optimum visualization of bands.)

Figure 2. Agarose gel electrophoresis pattern of DNA derived from thymic lymphocytes from (A) $\mathrm{BCF}_{1},(\mathrm{~B}) w s t / \cdot$, or (C) wst/wst mice. Cells were untreated ( $0 \mathrm{cGy}$ ) or exposed to $50-600 \mathrm{cGy}{ }^{60} \mathrm{Co} \gamma$ rays as indicated. Samples were pooled from 2 to 4 mice. All cells were harvested $3 \mathrm{~h}$ after completion of the irradiation.

Figure 3. Agarose gel electrophoresis pattern of DNA derived from splenic lymphocytes from $w s t / \cdot$ or $w s t / w s t$ mice. Cells were untreated (0) or exposed to $4.5 \mathrm{~Gy}(4.5){ }^{60} \mathrm{Co} \gamma$ rays as indicated. Samples were pooled from 2 to 4 mice. All cells were harvested $3 \mathrm{~h}$ after completion of the irradiation. 
Table I. DNA Fragmentation in Thymus After Radiation Exposure

\begin{tabular}{|c|c|c|}
\hline Mouse Strain & $\gamma$-ray Dose (cGy) & DNA Fragmented $(\%)^{\mathbf{a}}$ \\
\hline \multirow[t]{3}{*}{$\mathrm{BCF}_{1}$} & 0 & 0 \\
\hline & 50 & $7.7(0.1)$ \\
\hline & 150 & $4.3(4.3)$ \\
\hline \multirow[t]{2}{*}{. } & 450 & $32.8(6.7)$ \\
\hline & 600 & $\begin{array}{c}75.3(6.2) \\
-\end{array}$ \\
\hline \multirow[t]{5}{*}{ wst/. } & 0 & 0 \\
\hline & 50 & $16.6(1.6)$ \\
\hline & 150 & $\mathrm{ND}^{\mathrm{b}}$ \\
\hline & 450 & $30.1(9.8)$ \\
\hline & 600 & $16.0(2.6)$ \\
\hline \multirow[t]{5}{*}{ wst/wst } & 0 & $30.5(4.3)$ \\
\hline & 50 & $29.8(11.8)$ \\
\hline & 150 & $87.5(12.5)$ \\
\hline & 450 & $73.5(8.6)$ \\
\hline & 600 & 0 \\
\hline
\end{tabular}

"All assays done $3 \mathrm{~h}$ after exposure. Numbers in parentheses are SD.

${ }^{\mathrm{b}} \mathrm{ND}=$ not done 
Table II. DNA Fragmentation in Spleen After Radiation Exposure

\begin{tabular}{ccc}
\hline Mouse Strain & $\gamma$-ray Dose (cGy) & DNA Fragmented $^{2}$ \\
\hline BCF $_{1}$ & 0 & 0 \\
& 150 & $20.0(0)$ \\
& 450 & $16.7(0.7)$ \\
wst/. & 0 & 0 \\
& 50 & $21.0(0.9)$ \\
& 450 & $78.3(0.7)$ \\
wst/wst & 0 & $37.8(4.8)$ \\
& 150 & $45.7(2.3)$ \\
& 450 & 0 \\
\hline
\end{tabular}

All assays done $3 \mathrm{~h}$ after exposure. Numbers in parentheses are SD. 
Table III. Gamma-ray-induced DNA Fragmentation in Thymocytes After Cycloheximide 'Treatment"

\begin{tabular}{|c|c|c|c|}
\hline Mouse Strain & Radiation Dose (cGy) & $\begin{array}{c}\text { Cycloheximide } \\
\text { Concentration }(\mu \mathrm{g} / \mathrm{mL})\end{array}$ & $\begin{array}{c}\text { DNA } \\
\text { Fragmerted }(\%)^{\mathrm{b}}\end{array}$ \\
\hline \multirow[t]{6}{*}{$\mathrm{BCF}_{1}$} & 0 & 0 & $12.1(1.6)$ \\
\hline & & 25 & 0 \\
\hline & & 50 & $5.4(1.4)$ \\
\hline & 450 & 0 & $79.9(21.2)$ \\
\hline & & 25 & $29.7(10.0)$ \\
\hline & & 50 & $17.4(17.4)$ \\
\hline \multirow[t]{6}{*}{ wst. } & 0 & 0 & $6.0(2.8)$ \\
\hline & & 25 & $1.6(1.6)$ \\
\hline & & 50 & $7.3(4.4)$ \\
\hline & 450 & 0 & $40.3(18.7)$ \\
\hline & & 25 & 0 \\
\hline & & 50 & 0 \\
\hline \multirow[t]{6}{*}{ wst/wst } & 0 & 0 & $19.5(1.2)$ \\
\hline & & 25 & 0 \\
\hline & & 50 & $5.8(5.7)$ \\
\hline & 450 & 0 & $44.0(8.2)$ \\
\hline & & 25 & $9.5(9.5)$ \\
\hline & & 50 & 0 \\
\hline
\end{tabular}

${ }^{2}$ Cycloheximide treatment was given $10 \mathrm{~min}$ before irradiation. Cells were harvested $3 \mathrm{~h}$ after radiation exposure.

${ }^{\mathrm{b}}$ Numbers in parentheses are SD. 
$\frac{\pi}{\frac{\pi}{n}}$

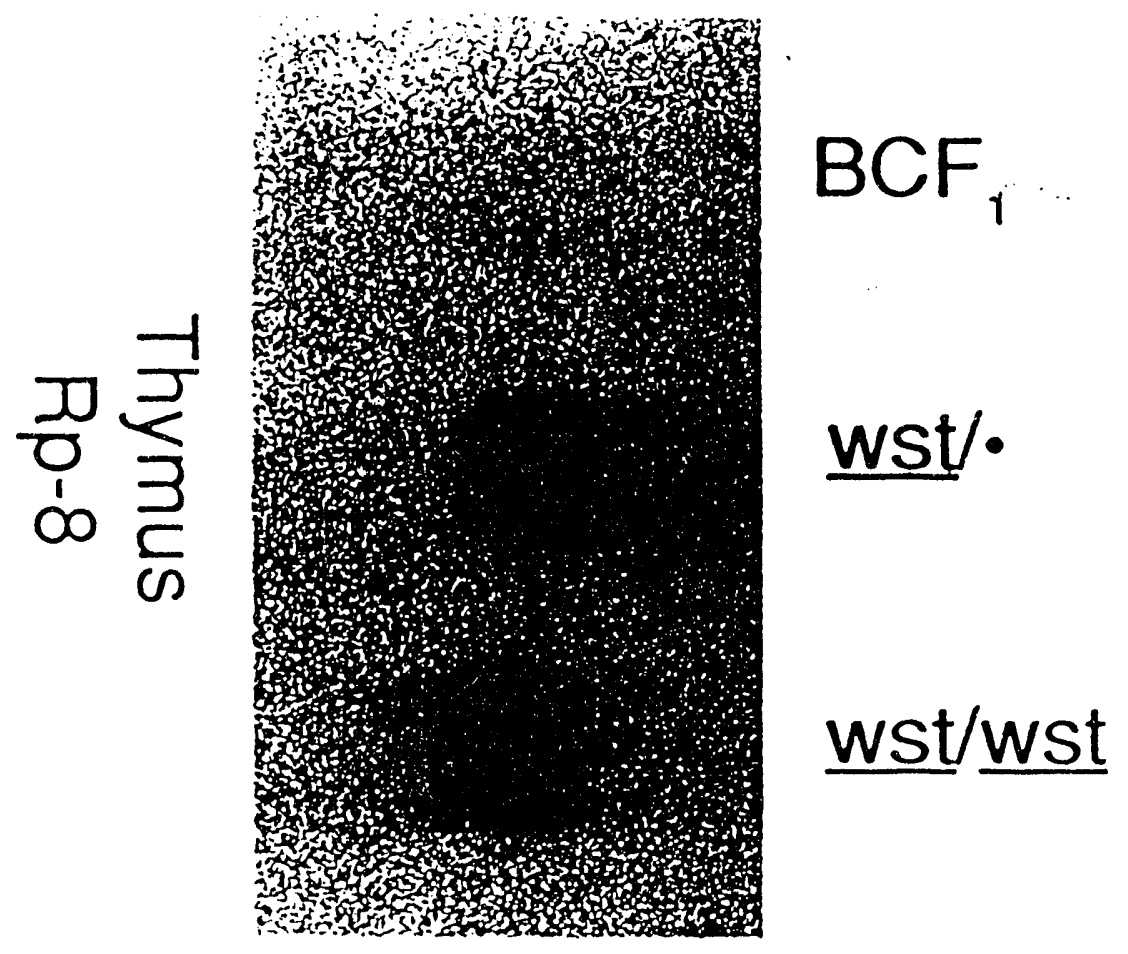



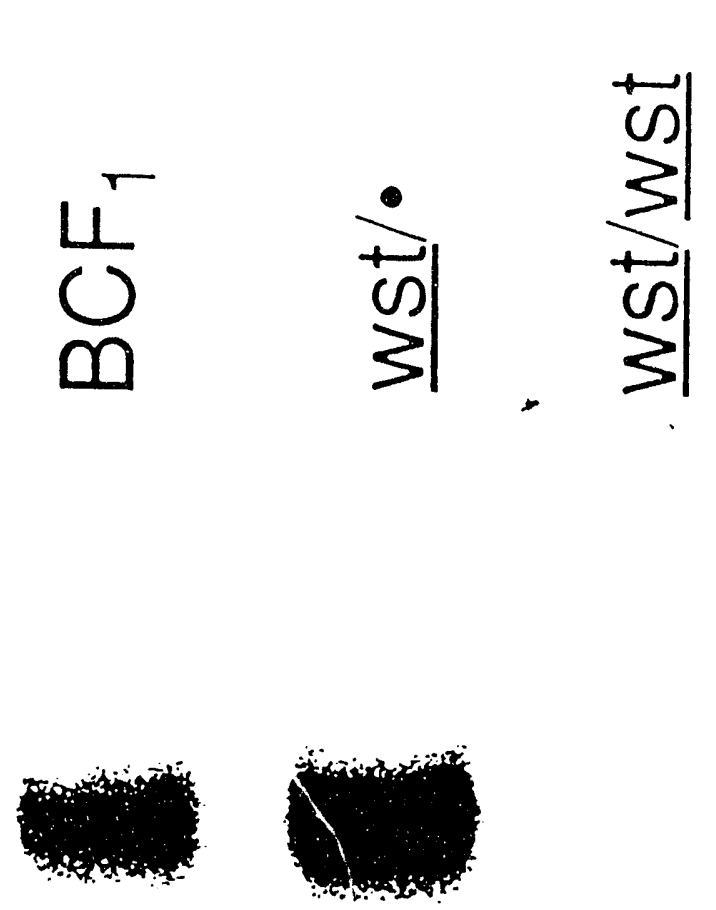

\section{Spleen Rp8}



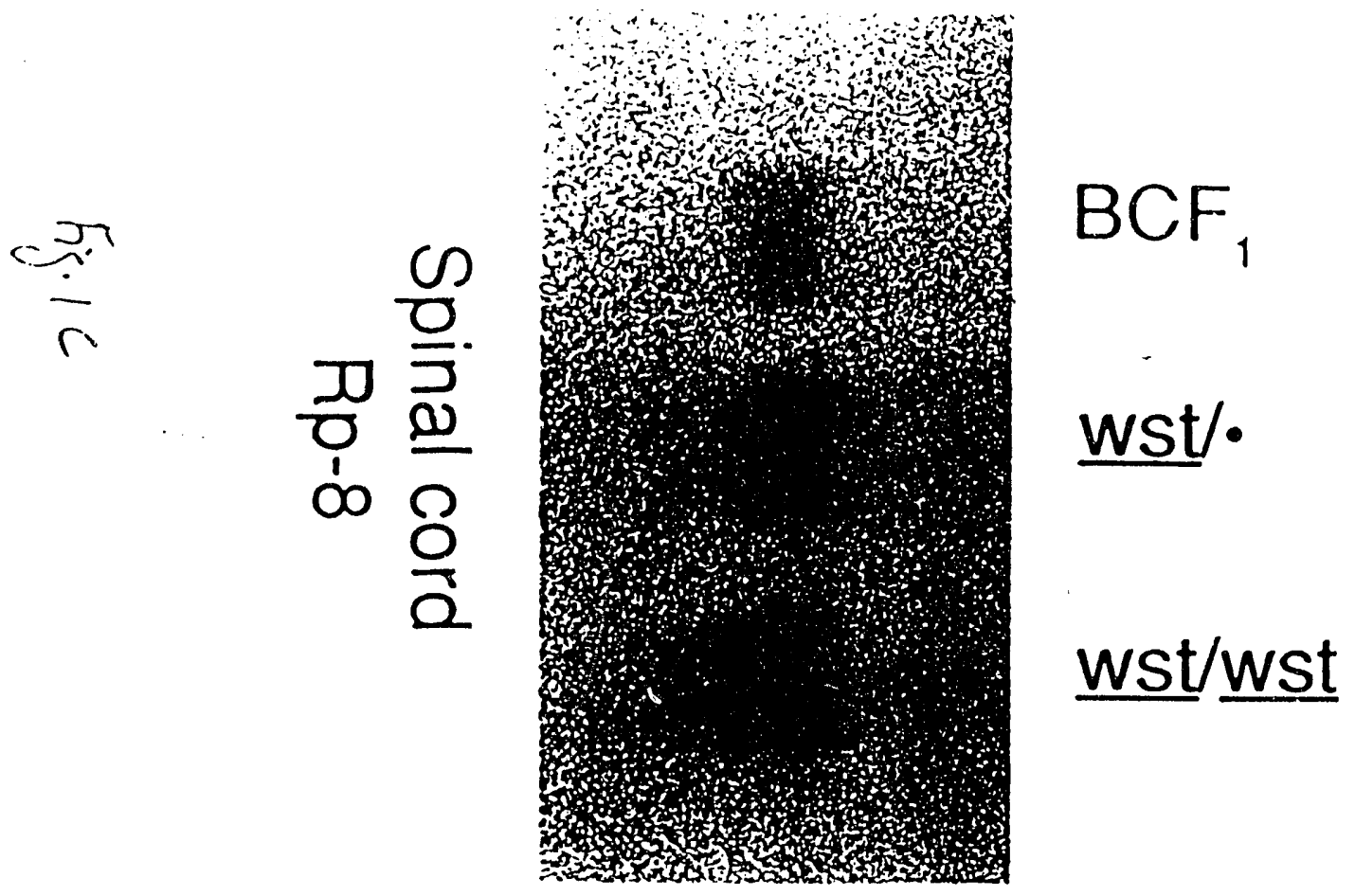


$$
\frac{\pi}{3}
$$

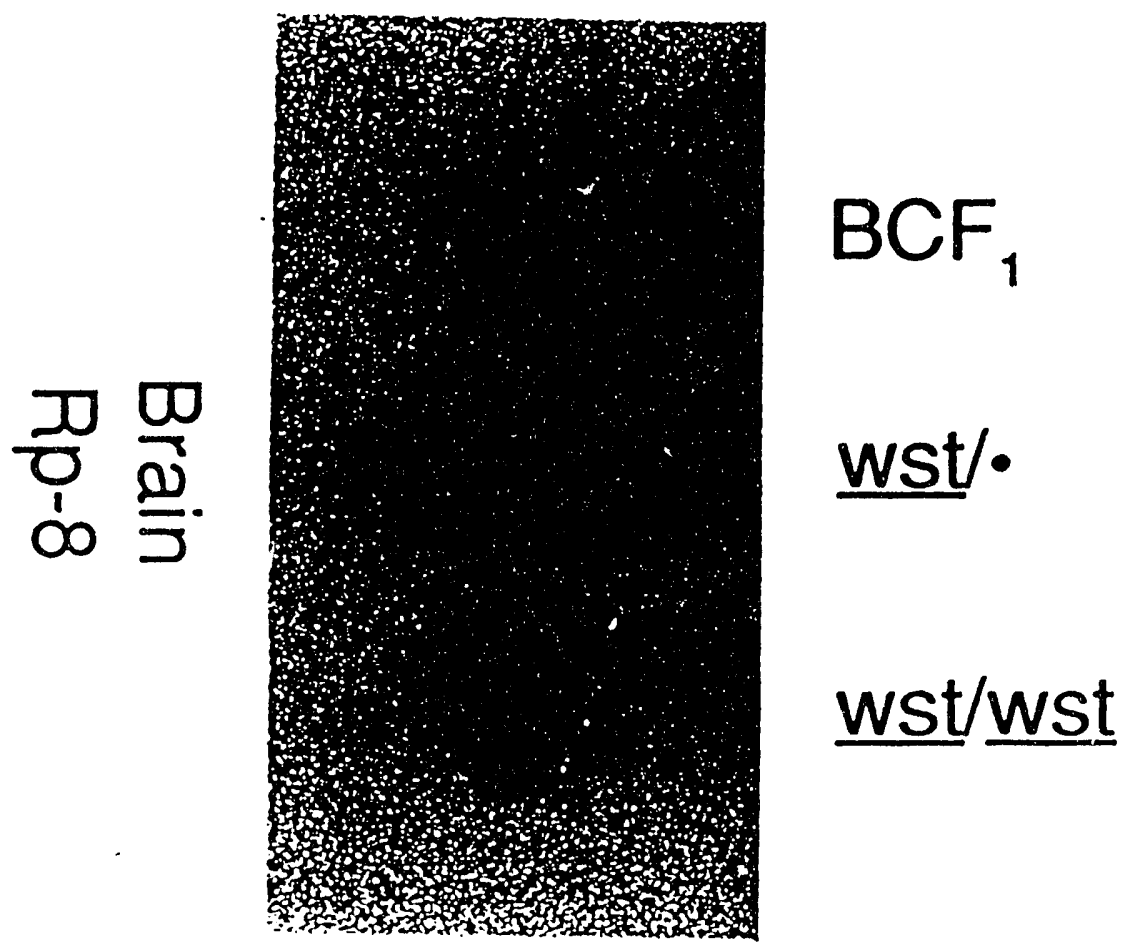




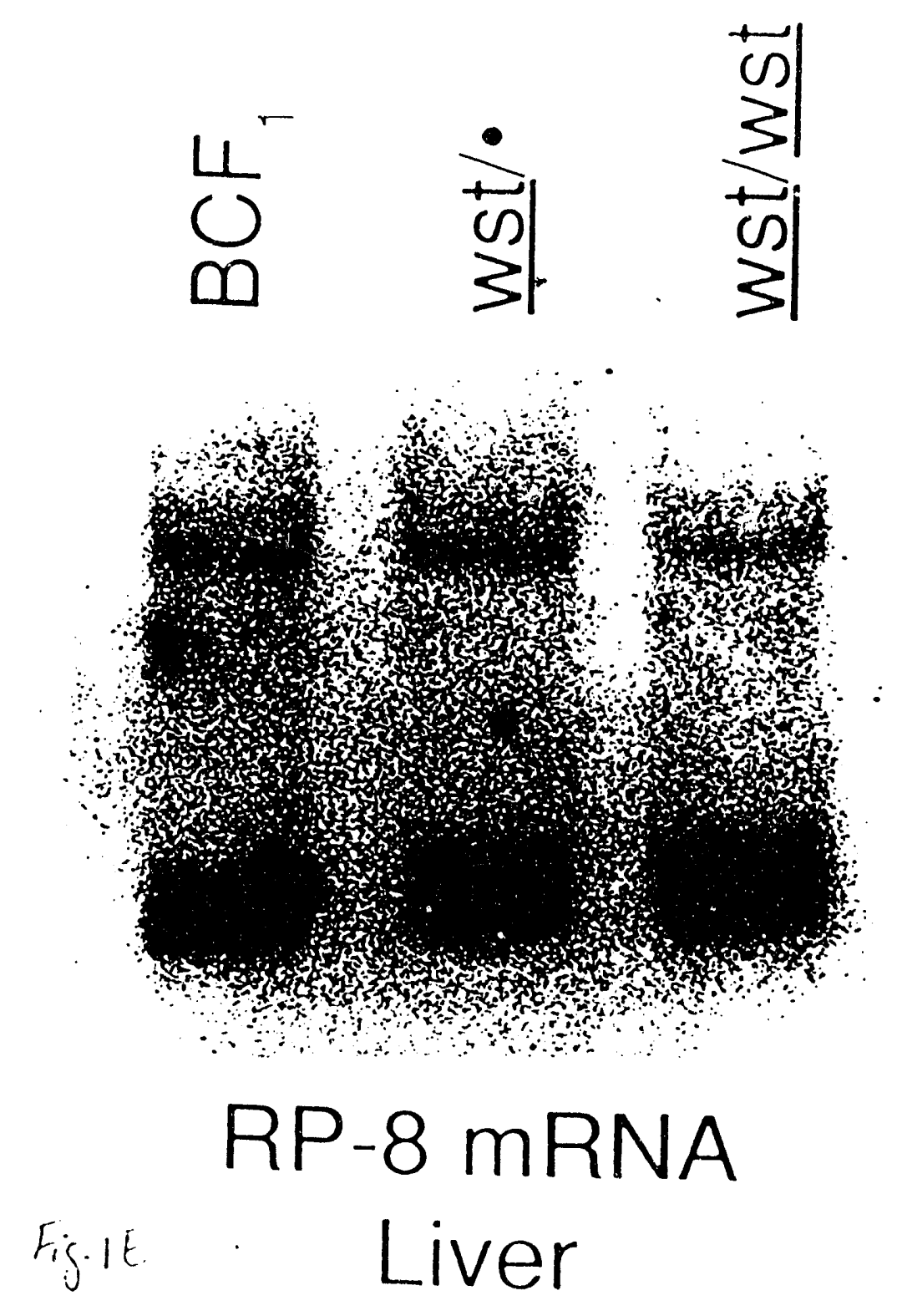




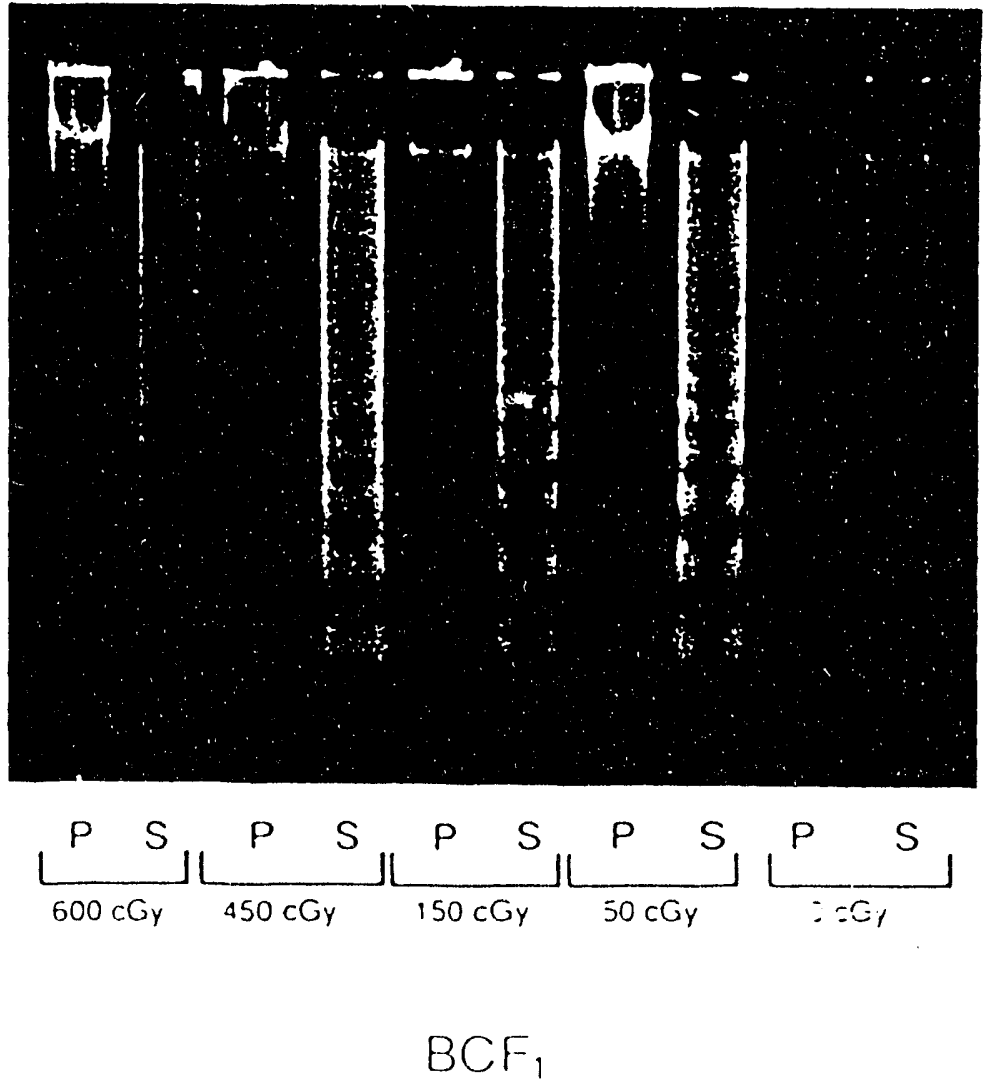

$\lg 2 A$ 


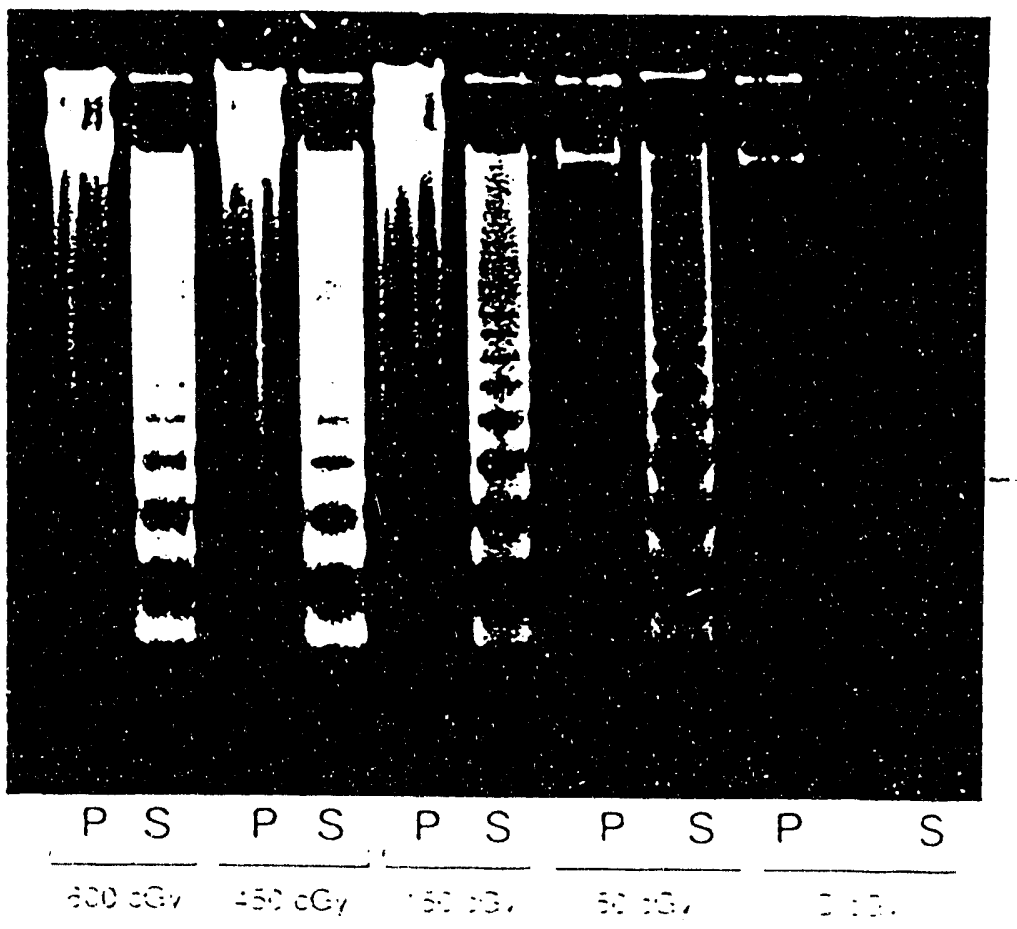

wst - Thymus

Fig. $2 B$ 



\section{in}
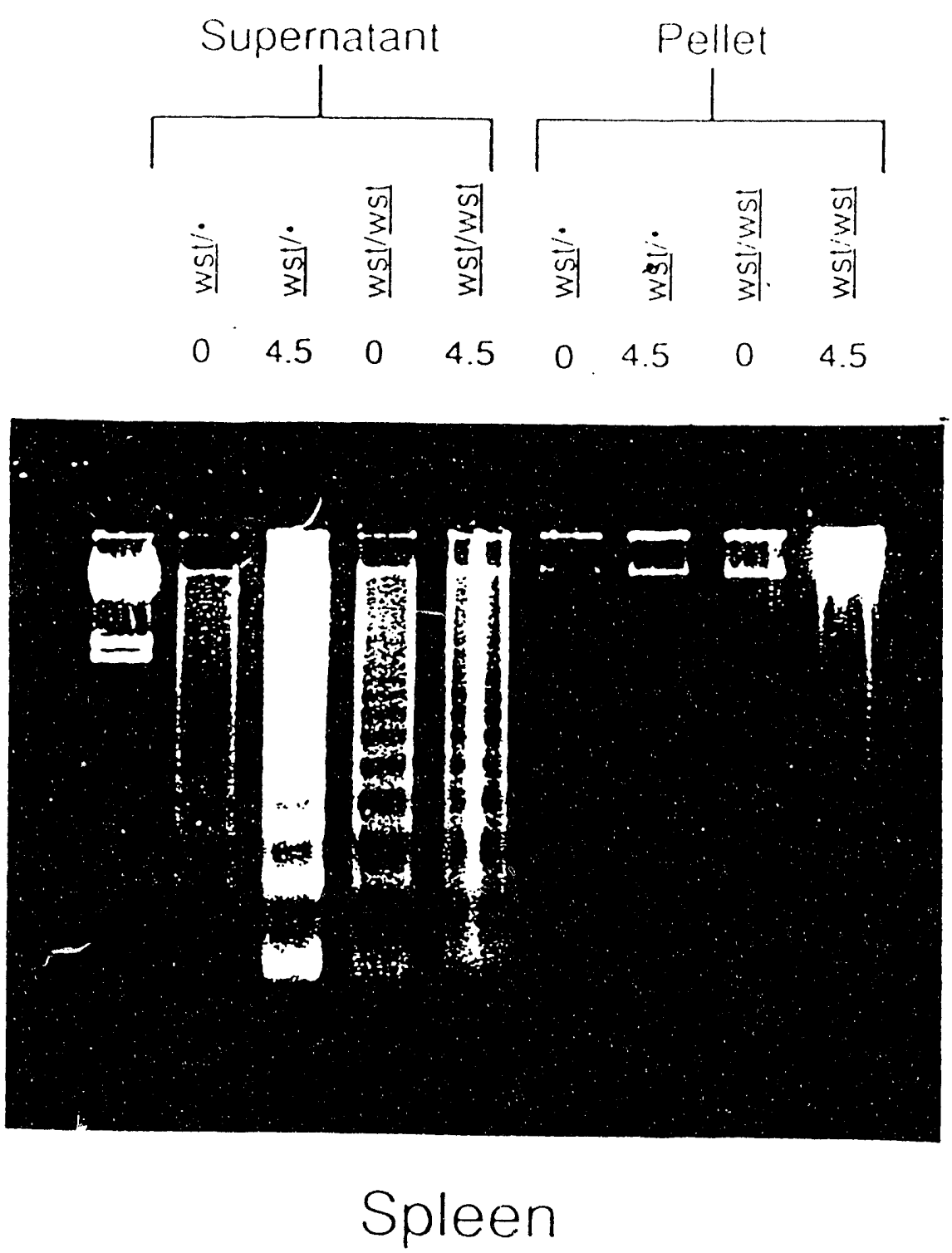

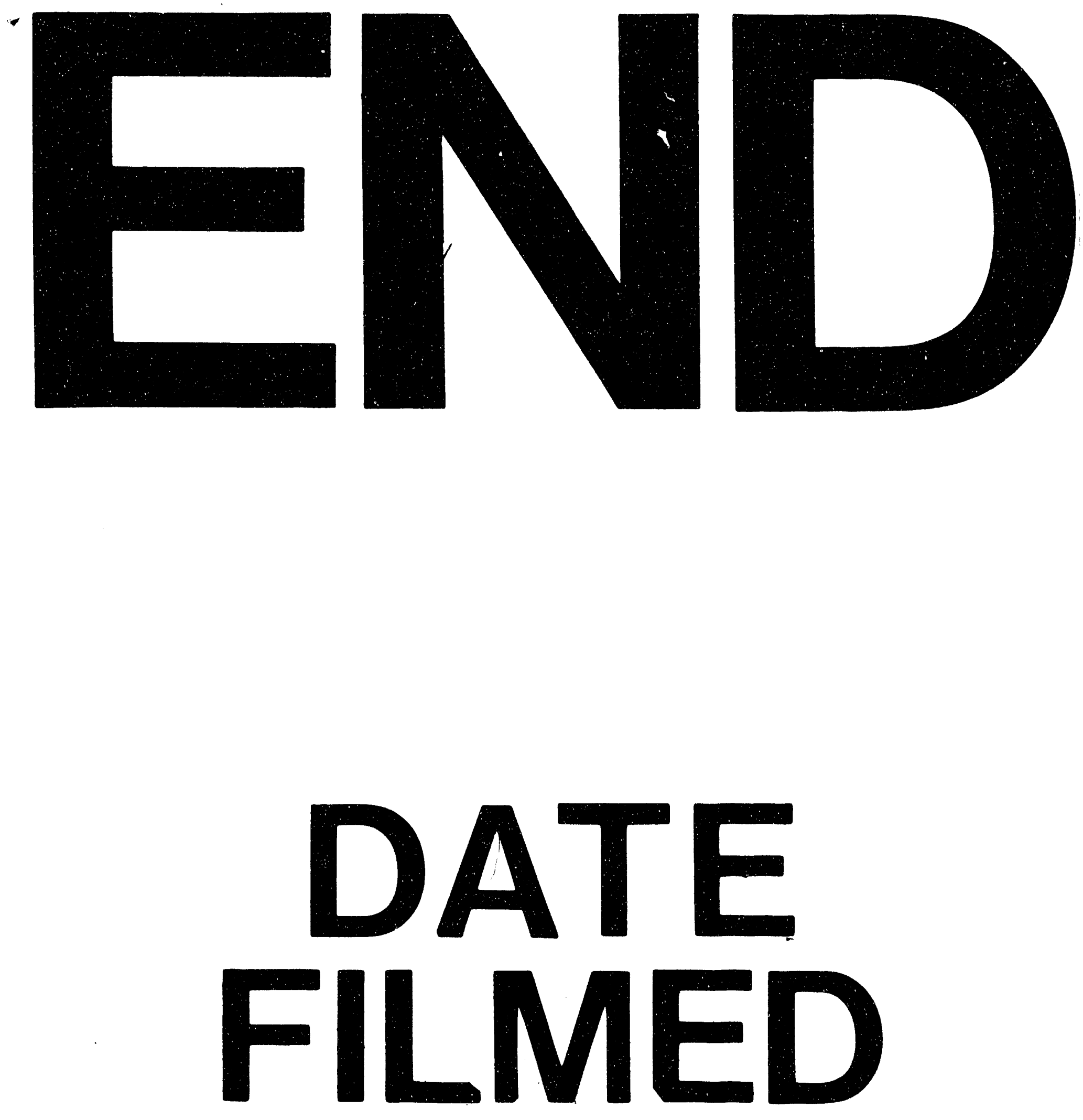

1

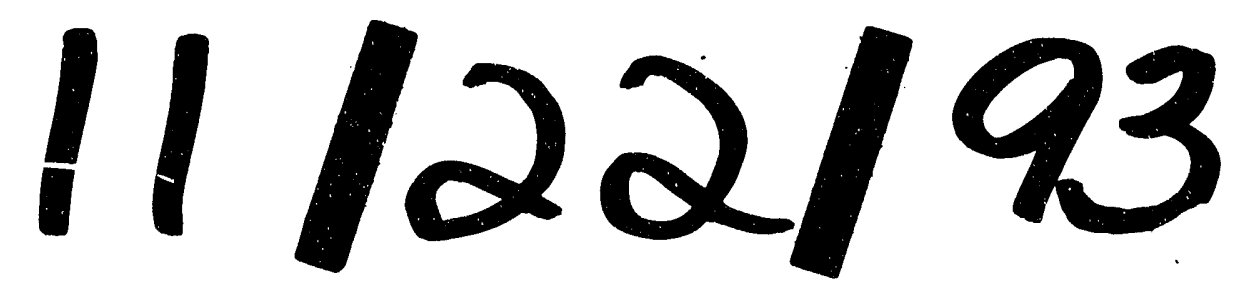


